Tjalling C. Koopmans Research Institute

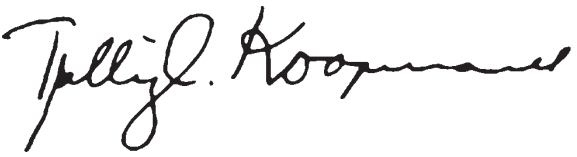

Discussion Paper Series nr: 05-31

\title{
Labour Mobility and Regional Disparities: The role of female labour participation
}

Sjef Ederveen

Richard Nahuis

Ashok Parikh 


\section{Tjalling C. Koopmans Research Institute Utrecht School of Economics \\ Utrecht University}

Vredenburg 138

3511 BG Utrecht

The Netherlands

telephone $\quad+31302539800$

fax $\quad+31302537373$

website www.koopmansinstitute.uu.nl

The Tjalling C. Koopmans Institute is the research institute and research school of Utrecht School of Economics.

It was founded in 2003, and named after Professor Tjalling C. Koopmans, Dutch-born Nobel Prize laureate in economics of 1975.

In the discussion papers series the Koopmans Institute publishes results of ongoing research for early dissemination of research results, and to enhance discussion with colleagues.

Please send any comments and suggestions on the Koopmans institute, or this series to M.Damhuis@econ.uu.nl

ontwerp voorblad: WRIK Utrecht

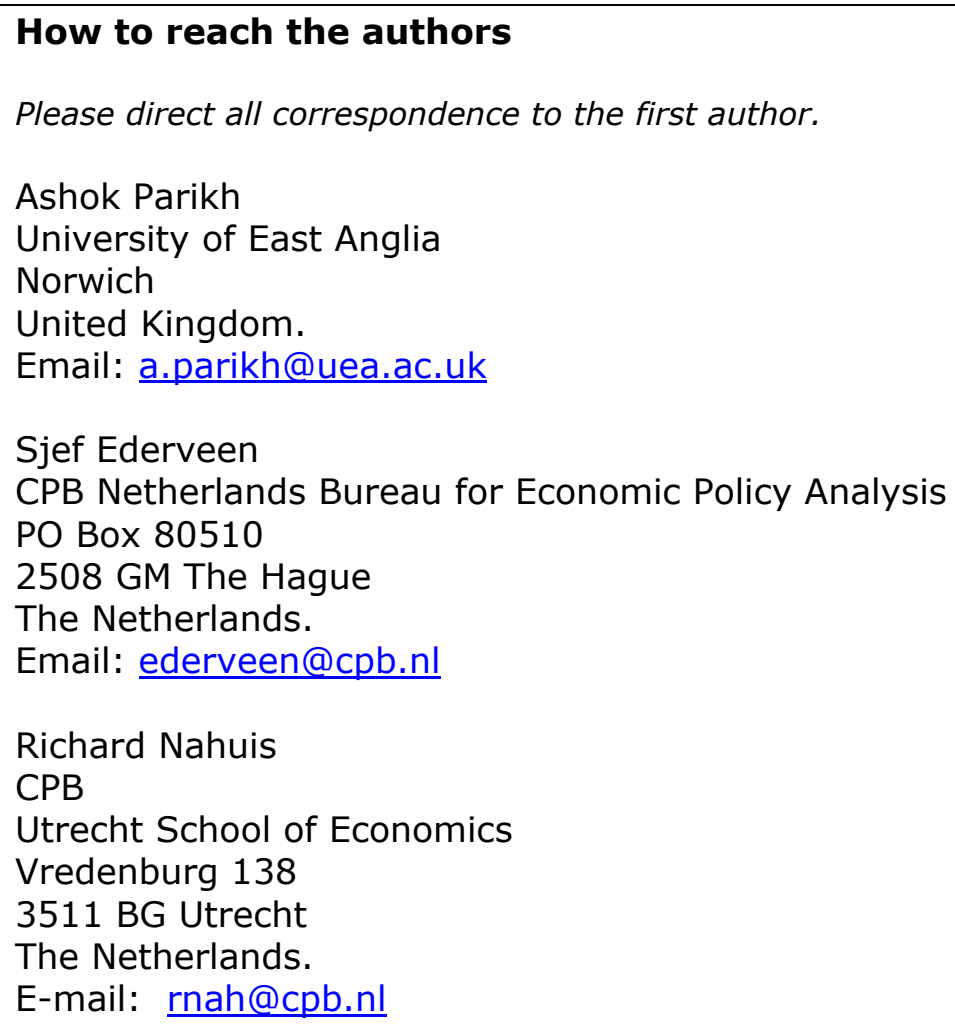

This paper can be downloaded at: http://www.koopmansinstitute.uu.nl 


\title{
Labour Mobility and Regional Disparities: The role of female labour participation
}

\author{
Sjef Ederveen ${ }^{a}$ \\ Richard Nahuis ${ }^{\text {ab }}$ \\ Ashok Parikhc
}

${ }^{\mathrm{a}} \mathrm{CPB}$ Netherlands Bureau for Economic Policy Analysis

bUtrecht School of Economics

Utrecht University

' University of East Angli United Kingdom

October 2005

\begin{abstract}
Unemployment rates as well as income per capita differ vastly across the regions of Europe. Labour mobility can play a role in resolving regional disparities. This paper focuses on the questions why labour mobility is low in the EU and how it is possible that it remains low. We explore whether changes in male and female labour participation act as an important alternative adjustment mechanism. We answer this question in the affirmative. We argue that female labour participation is very important in adjusting to regional disparities.
\end{abstract}

Keywords: Labour Mobility, Labour Participation, European Union

JEL classification: F22, J61

Acknowledgements

Comments by Ruud de Mooij and two anonymous referees considerably improved the paper. Richard Crum, Jan Fidrmuc, George Gelauff, Joeri Gorter and Theo van de Klundert are acknowledged for comments on a previous version of the paper. 


\section{Introduction}

The desire to establish the four freedoms belonging to the formation of a common marketfree movement of goods, services, persons and capital - was written into the Rome Treaty. The integration project formed, relatively successfully, a single goods and capital market. Currently, the European Commission undertakes serious efforts to tackle the problems preventing an effective single services market. The free movement of persons is de facto the black sheep in the integration process as (cross-border) migration is still very low.

The 25 members of the European Union constitute a large set of diverse regions. This is partly due to the accession of ten new member states in 2004, but even the fifteen old members constitute a heterogeneous set of countries. They not only differ in labour market outcomes, such as unemployment rates and wages, but also in industry structure (MidelfartKnarvik et al., 2000). This makes Europe relatively vulnerable to asymmetric shocks (Bayoumi and Eichengreen (1993), something which might be amplified by a better functioning of the single market (Krugman, 1993) ${ }^{1}$.

Labour mobility can play a role in adjusting to shocks. In a single currency area the adjustment to asymmetric shocks can take place via price or quantity adjustment, or via fiscal transfers. In particular, real wages ought to be flexible, fiscal redistribution should be of sufficient size, or capital, labour and income flows should be sufficiently responsive to disturbances. ${ }^{2}$ In the EU fiscal redistribution is relatively unimportant compared to the US, while wage flexibility is known to be notoriously low. However, it is not clear that the role for labour mobility is or can be important in absorbing short term shocks. Hence, for the largest part of the analysis here we focus on long term or permanent shocks.

Labour mobility can play a role in resolving regional disparities. Unemployment rates as well as incomes per capita differ vastly across regions. Midelfart-Knarvik et al. (2000) show that the industry structure is also very diverse across the EU and is becoming even more so. Barro and Sala-i-Martin (1991) and Barro (1996) assert that per capita incomes tend to converge but that complete convergence is still out of sight. Putting these pieces together, the point that there is a potential role for labour mobility in resolving regional disparities is easily made. Indeed, it is low mobility in the presence of large regional disparities that is worrying. Hence

\footnotetext{
${ }^{1}$ This is disputed, however, by Fatas (1998) and Frankel and Rose (1997).

${ }^{2}$ It is not a priori clear that the disappearance of the exchange rate instrument is an unambiguous loss. Many countries have abstained from using the exchange rate as an instrument for shock adjustment.
} 
what is crucial is the responsiveness of labour to regional disparities and, thus, explaining the responsiveness is important. This is what this paper sets out to do.

Closely related to our approach are Decressin and Fatás (1995) and Puhani (2001). Decressin and Fatás (1995) use the methodology of the seminal study of Blanchard and Katz (1992) to show that the responsiveness of European regional labour mobility is slow and low relative to the US. They find that in the short run an idiosyncratic shock in Europe is absorbed for the most part by labour participation, with only a minor role for migration. Also in the long run the role for labour mobility is low compared to the US. The major adjustment mechanism is again the change in labour participation rates. Changes in unemployment rates account only for a small portion of the change in regional employment.

Puhani (2001), using a different methodology, explains net migration rates by regional disparities (instead of region-specific shocks). He finds that only unemployment rates significantly explain migration. His methodology is closely related to ours, but he does not consider the role of labour participation.

This paper focuses on the questions why labour mobility is low in the EU and how it is (apparently) possible that it remains low. We explore the issue of labour participation, thrown up by Decressin and Fatás (1995), as the most important alternative adjustment mechanism. In particular, our analysis contains three main contributions to the literature. First, using a framework different from Decressin and Fatás we address the question on labour participation as an alternative adjustment mechanism for labour mobility in the EU. Second, we examine whether labour participation of females is important or whether labour participation is important in general. Third, we use a more finely disaggregated data-set than Decressin and Fatás and Puhani and include more regions. Furthermore, by treating the EU regions as a single panel we are able use more information in the identification of the parameters.

The paper is organized in six sections. Section 2 presents the theoretical considerations behind our estimating equation of net migration. Section 3 describes the data used and discusses its limitations. Section 4 presents the econometric estimation from the static model applied to panel data of the regions of EU. Furthermore it draws inferences from the static econometric model applied to the regions of the EU. Section 5 formulates a partial adjustment model for the net migration rate. The dynamic model is estimated using the Arellano-Bond estimator. The estimated adjustment coefficients permit us to study both short 
run and long run responses of net migration rates to unemployment, income and other labour market variables. Section 6 draws some conclusions.

\section{2: Theoretical considerations behind the net migration equation}

The role that labour mobility plays in resolving aggregate regional disparities is captured by net migration flows. ${ }^{3}$ This section presents the theoretical considerations behind the migration equation that we estimate in the next sections of this paper.

\section{Wages and unemployment}

What induces a migrant to move to a different region? This question is the central theme of this paper. Central in most theoretical models is the impact of wages and unemployment. The idea is that labour migration is driven by differences in expected earnings. This approach is generally ascribed to Harris \& Todaro $(1970)^{4}$. Their original model describes migration from rural areas to the city in a developing economy but can also be applied more generally to migration between regions. In this model the migration decision is based on the expected earnings from employment; people move if the expected wage to a destination region is higher than at home. The expected wage depends on the prospects of finding a job and average wages in a particular region. In this model equilibrium is brought about by labour mobility: migration between regions will continue until the expected earnings from employment are the same in each country. According to this theory, high unemployment and lower wages therefore lead to lower immigration in the country in question.

In the Harris-Todaro model the expected wages (after adjustment for migration costs) in all regions are the same in the long term. This is not very realistic. Even between the 15 old member states of the European Union the differences are marked: net hourly pay in the Netherlands is for example over 50\% higher than that in Portugal, while unemployment in the Netherlands is lower than that in Portugal. The outcome becomes more realistic by accepting that better facilities or a pleasant climate compensate for the ensuing differences in wages and unemployment. The expected earnings from employment may differ but the expected utility

\footnotetext{
${ }^{3}$ Gross flows of workers that are not identical with respect to skill, might be resolving disquilibria on specific labour markets. Due to a lack of suitable data this issue could not be analysed.

${ }^{4}$ This approach had a number of early forerunners in Smith (1776), Ravenstein (1889) and Hicks (1932).
} 
remains the same. This effect can be incorporated in the estimation equation by including fixed effects.

\section{Labour participation}

Except for static differences between regions that make one region more attractive than another, the dynamic adjustment process may differ between regions. One reason for this may be country specific, like differences in labour market institutions in the various member states of the European Union. For instance, stricter employment protection legislation and a higher replacement rate impact the decision to supply labour. Furthermore, regional differences may play a role as well. Regional differences in housing markets can alter the speed of adjustment to labour market shortages. If finding a house in a certain region is hard and the costs associated are prohibitive, migration to that region will be relatively low. For the same reason, people may stay in that region when they lose their job and stop participating in the labour market. When economic conditions improve, these people may enter the labour market again. In this way regional differences imply a different adjustment mechanism. Another possible source of variation between regions is culturally-determined differences in attitudes and preferences. It is for example often argued that the family is more important in Southern Italy than in, say, the United Kingdom. As a result, migration will be less of an option for individuals in the Mezzogiorno. For all these reasons, regional labour markets may adjust in a different way and at a different speed to regional disparities. In a more 'flexible' region, higher wages and lower unemployment will strongly encourage labour supply. In these regions, labour market participation will be the most important adjustment mechanism with only a minor role for labour mobility. Hence, we would expect that a strong reaction of labour supply has a negative effect on immigration.

These regional differences in adjustment can easily be captured in a standard model of migration. We start from the familiar Harris-Todaro framework. In that model, migration is determined by the prevailing wage level and the chance of finding a job in a certain region. The migration equation then reads (see e.g. Puhani, 2001):

$$
\operatorname{MNig}_{i t}=A_{i t}\left(u_{i t}^{\alpha_{1}} w_{i t}^{\alpha_{2}}\right)
$$

where $M N i g_{\text {it }}$ is the immigration rate, $u_{\text {it }}$ is the unemployment rate and $w_{\text {it }}$ is the wage level in region it at time t. 
In this model, the effect of differences in wages and unemployment on migration will be the same for all regions. However, as we discussed above, this will normally not be the case. The capacity of a region to adjust for shocks is determined by the flexibility of its labour market. At one extreme, a completely flexible region can solve any regional disparities on its own (people can be fired easily in bad times and participation increases when demand for labour is high); at the other extreme, the adjustment process in a completely inflexible region depends enitrely upon the attraction offered to immigrants. When we extend the model to capture this effect we get:

$\operatorname{MNig}_{i t}=A_{i t}\left(u_{i t}^{-\alpha_{1}} w_{i t}^{\alpha_{2}}\right)$ flex $_{i t}^{-\alpha_{3}}$

and rewriting with log transformation we obtain

$\ln \left(M N i g_{i t}\right)=\tilde{A}_{i t}-\alpha_{1} \ln \left(u_{i t}\right)+\alpha_{2} \ln \left(w_{i t}\right)-\alpha_{3} \tilde{f l e x}_{i t}$

We can not directly observe the labour market flexibility of a region. However, labour participation can act as a proxy for the flexibility in the labour market. As we discussed above, migration is not the only way to resolve regional disparities. In particular, labour supply in a 'flexible' region will adjust strongly to economic incentives. This effect is captured in the following equation for female labour participation:

$\Delta$ FemPart $_{i t}=B_{i t}\left(u_{i t}^{-\beta_{1}} w_{i t}^{\beta_{2}}\right) *$ flex $_{i t}$

Or, equivalently:

$\Delta$ FemPart $_{i t}=\tilde{B}_{i t}-\beta_{1} \ln \left(u_{i t}\right)+\beta_{2} \ln \left(w_{i t}\right)+\tilde{f l e x}_{i t}$

This type of participation equation is common to the labour supply literature. For instance, in a recent contribution to this literature Genre et al. (2005) estimate such a model for a panel of EU countries in which they use different institutional variables like replacement rates and union density to account for the flexibility of a region's labour market. They estimate this equation both for prime-age males and females and find that female participation is sensitive to unemployment, whereas male participation is not significantly influenced by economic conditions. In most other studies female labour supply is also found to react more strongly than male labour (see e.g. Hausman and Ruud, (1984) and Devereux, (2004)). Because of these differences in the responsiveness of male and female labour supply, we focus on female labour market participation in the remainder of the analysis. Moreover, we will also include 
male labour participation separately in the regression analysis for establishing the robustness of the results.

When we combine equations (3) and (5) and reparameterise we obtain:

MNig $_{i t}=C_{i t}-\gamma_{1} \ln \left(u_{i t}\right)+\gamma_{2} \ln \left(w_{i t}\right)-\gamma_{3} \Delta$ FemPart $_{i t}$

This is the equation that we will estimate in the econometric analysis in section 4 . If our hypothesis is right, the change in female labour participation will enter negatively in the migration model. The reason is that in a more flexible regional labour market, female labour supply takes the place of migration as the most important adjustment mechanism.

\section{Other theoretical considerations}

The discussion above deals with a general framework of regional differentials that possibly influence migration. Of course, specific individual and household characteristics may have a separate impact. By including fixed effects for each region in our regression analysis, we can account for structural differences in the demographic composition of a region. Bauer and Zimmermann (1995) suggest that migration may become a self-perpetuating process, because the costs and risks of migration are lowered by social and information networks ${ }^{5}$. The network approach indicates that the cost of moving may be substantially reduced for the relatives and friends of migrants, and this could increase the probability of migration. The network effect of migration hence implies that migration induces more migration. We will touch upon this issue by considering a dynamic specification of our econometric model where partial adjustment formulation is presented.

Countrywide unemployment levels tend to discourage migration as it makes migration riskier. Moreover, credit-market conditions might worsen in recessions making it difficult to finance the mobility cost (see, Gordon, 1985). That aggregate unemployment affects gross flows negatively does not, however, deliver a clear prediction for net flows, hence we do not pursue this line here (Pissarides and McMaster, 1990, elaborate on this).

\footnotetext{
${ }^{5}$ The network approach indicates that the cost of moving may be substantially reduced for the relatives and friends of migrants, and this could increase the probability of migration. The network effect of migration hence implies that migration induces more migration. However, our model does not consider explicitly network hypothesis. Our model combines adjustment to the desired level of migration using other considerations such as lagged effects and discouraged worker effect in times of recession.
} 


\section{Data: description and limitations}

We use regional data at the Nuts 2 level from the Regio database of Eurostat, the statistical office of the European Union. Nuts 2 ('nomenclature of territorial units for statistics') subdivides the territory of the European Union into 211 regions. An average Nuts 2-region has 2.2 million inhabitants (take for instance Hanover in Germany). Two European regions at the Nuts 2 level are identical to countries: Luxembourg and Denmark. We use data on population changes and economic variables, like GDP, and labour market data, as unemployment and participation rates. From the available information of regions we select those regions which provide the necessary data to construct net migration rates. This provides us with an unbalanced panel of 191 regions with time-series of up to 18 years (1983-2000). Constructing a balanced panel with the time-series dimension unaltered reduces the number of regions to 83 (for details on the regions included in this panel see Appendix A).

We calculate data on net migration as the population change plus deaths minus births. The fact that we use population migration where labour migration is relevant for the labour market impact requires some discussion. First, the data do not allow us to distinguish between labour migration and population migration. Second, there is evidence that qualitatively comparable results are obtained using either labour or population-migration data (see Van Leuvensteijn and Parikh, (2002)). Finally, systematic biases in the difference between population and labour migration (think of a region with a large university) will end up in fixed effects. The unsystematic bias is white noise. 
Table 3.1 Summary Statistics ${ }^{\mathrm{a}}$

\begin{tabular}{|c|c|c|c|c|}
\hline Variable & Mean & Std Dev & Minimum & Maximum \\
\hline$G D P^{b}$ & 14185.4 & 4785.2 & 5053.1 & 46906.8 \\
\hline Unemployment Rate & 9.1 & 4.2 & 1.5 & 27.4 \\
\hline Female Activity rate & 41.6 & 6.8 & 22.0 & 62.4 \\
\hline Male Activity rate & 65.7 & 4.4 & 52.4 & 78.0 \\
\hline Population $^{c}$ & 2253.6 & 1809.7 & 222.8 & 11088.2 \\
\hline Net Migration ${ }^{d}$ & 2.8 & 5.5 & -29.1 & 47.98 \\
\hline
\end{tabular}

Notes ${ }^{\text {a }}$ The summary statistics are taken from the untransformed variables.

${ }^{\mathrm{b}}$ GDP per inhabitant at Purchasing Power Parities.

${ }^{\mathrm{c}}$ In Thousands

${ }^{\mathrm{d}}$ Multiplied by a Thousand

The explanatory variables for which the information is available are summarised in Table 3.1 (Appendix A provides detailed definitions for the different variables). As a proxy for the wage rate, we use GDP per inhabitant at purchasing power parity (GDP). ${ }^{6}$ The spread in GDP per inhabitant is large; the lowest income in the panel is measured in the Greek region of Thessalia in 1983; the highest level of income per capita is reported for the Belgium capital region of Bruxelles in 2000. Also the variation in unemployment rates is large: it varies from a low $1.5 \%$ (Luxembourg, 1991) to a high of $27.4 \%$ (Calabria, Italy in 1999).

The main other explanatory variable is the activity rate of females and the activity rate of males. As expected, male activity rates are much higher than female rates and do not show as much variation. Female labour market participation in Sicilia was throughout the period 1983-2000 never even half the figure for Denmark.

The population data are provided to illustrate the size of the regions. The mean size of a region is 2.25 million people. The mean rate of migration is 0.003 , hence the regions in the sample are, as an unweighted average, immigration regions. Hence a region with 2,200,000

${ }^{6}$ There is a structural break in the GDP data due to a revision in the European accounting system (ESA) in 1995. We have constructed the GDP series by assuming that GDP growth is correctly measured. 
inhabitants received 6,600 net migrants a year ${ }^{7}$ approximately. The mean rate of migration, 0.003 , might be low, but that is not the same as saying that migration is unimportant, as it is an important factor in explaining population changes, as we will illustrate below.

Figure 3.1 depicts the yearly average of the absolute value of the net migration rate in the sample.

Figure 3.1 : Net migration over time (multiplied by a thousand)

Figure 3.1 Net migration over time (average absolute value)

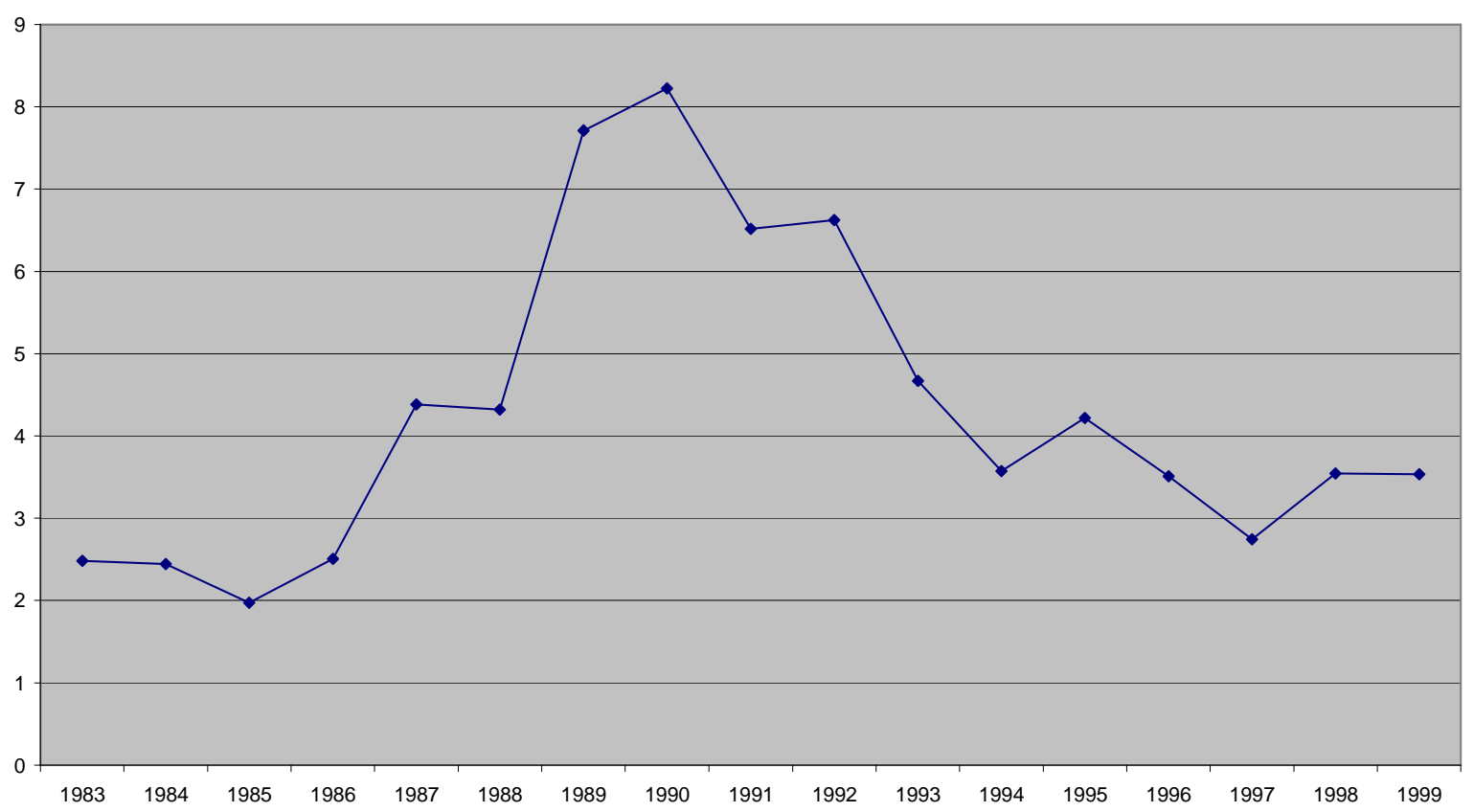

The spike around 1989, 1990 is to a considerable extent caused by the German unification. ${ }^{8}$ What deserves attention is that, despite further steps in the European integration process, the migration rate is almost back to its low rate of the early eighties. Two issues are important to judge the time-series behaviour of the net migration rate: first, what is the magnitude of migration compared to population change and second, how big is the incentive to migrate.

\footnotetext{
${ }^{7}$ That is: $2,200,000 * 3 / 1000$

${ }^{8}$ In the econometric analysis we include both time dummies and fixed effects to accoount for this event. The main findings that we present in the next section stand upright when we exclude Germany.
} 
First, the statement that the migration rate is low is different to suggesting that migration is unimportant. Figure 3.2 makes this point. It shows the share that migration contributes to population change. Figure 3.2 depicts the median observation ${ }^{9}$. This median share is roughly $50 \%$ to $80 \%$ and has not returned to the share level observed in the early eighties.

\section{Figure 3.2 Contribution of migration to population change}

Contribution of migration to population change

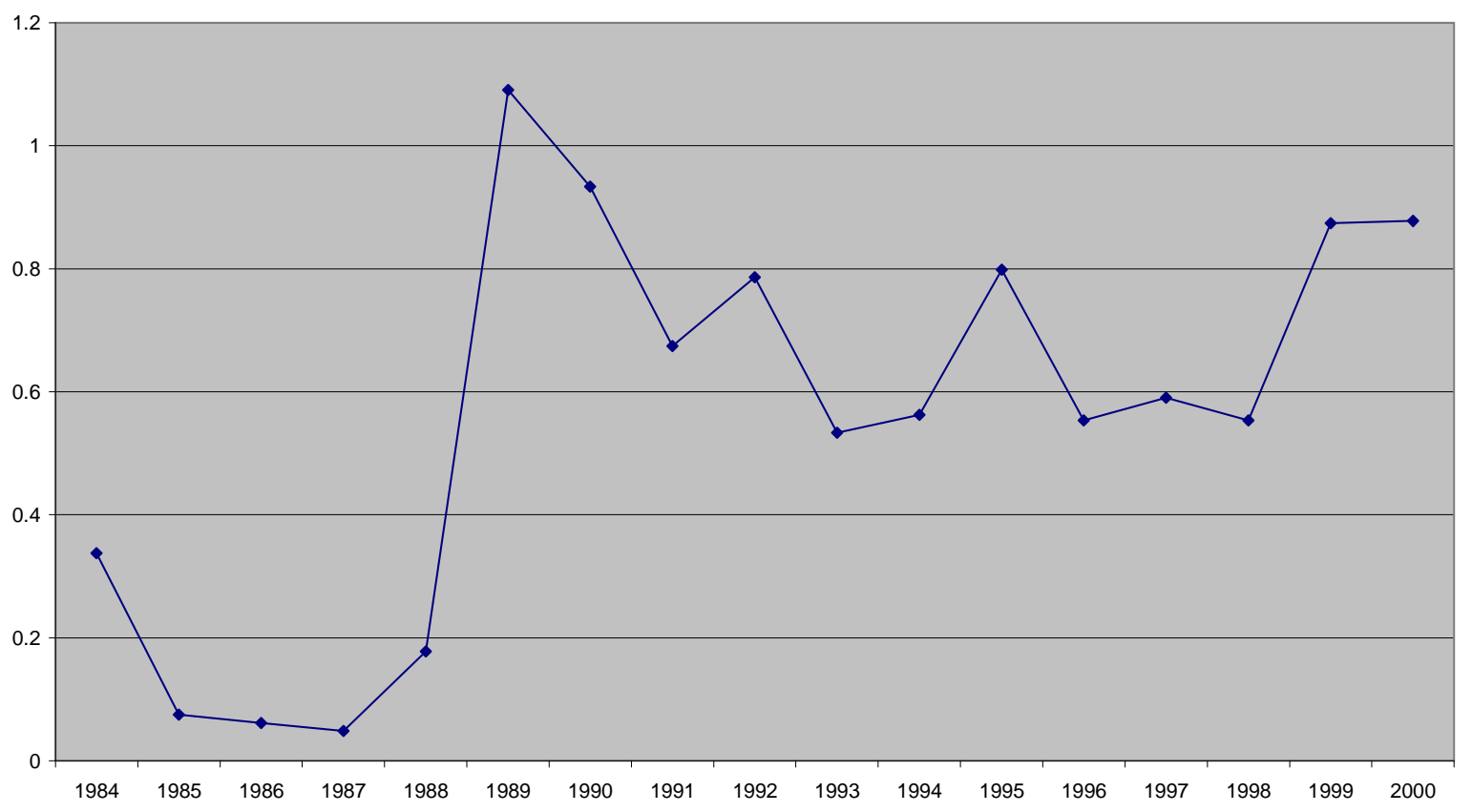

${ }^{9}$ We show the median of (Net migration / $\Delta$ population) instead of the mean; the mean is not as informative as the denominator tends to zero for several observations. 


\section{Figure 3.3 Variance of expected income and income}

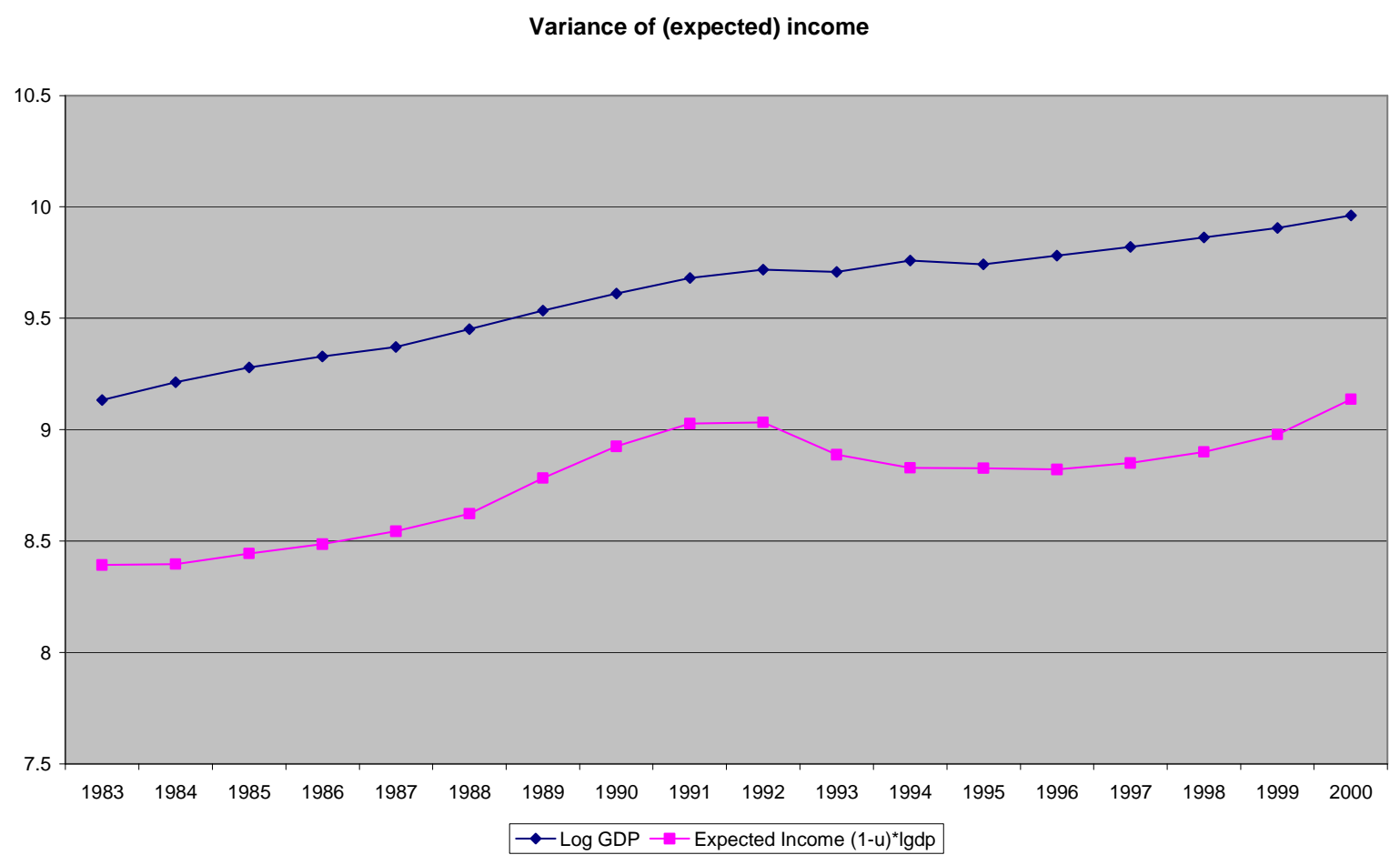

Second, the return to the relatively low rates of migration of the 1980's is not worrying as such, what matters is whether the rate of migration is low despite high incentives to migrate. Figure 3.3 presents some indicators of the incentives to migrate. The upper line in the figure depicts the variance of the log of per capita GDP. The slight increase indicates that the regions in our sample have not converged in the period under consideration (see, for a similar finding, Barro and Sala-i-Martin, 1991).

In Section 2 we argued that the relevant decision variable for migration is the chance of obtaining a job multiplied by the wage. To proxy for this, the lower line shows whether (1$\mathrm{U})^{*} \log$ GDP showed convergence; here also the opposite is true. ${ }^{10}$ The low rate of migration remains puzzling as the incentives for migration have gone up. Putting some pieces of this puzzle together is the issue to which we turn now.

${ }^{10}$ This finding is robust to the method of computing the variation in expected income. The coefficient of variation also produces an upward trend, as does this statistic with the level of income (without taking logs). 


\section{4: Econometric estimation and results}

As argued in section 2, we start from a standard model in the tradition of Harris and Todaro (1970), and add the female participation variable to see whether this acts as an alternative adjustment mechanism in the regions of the European Union. Our estimating equation is thus specified as:

$M N_{i t}=b_{0}+b_{1} \ln G D P_{i t}+b_{2} \ln U_{i t}+b_{3} \Delta A C T_{i t}+\varepsilon_{i t}$ where $\varepsilon_{i t}=\alpha_{i}+\eta_{i t}$

In which $M N$ is the net migration rate; $G D P$ per capita is used as a proxy for differences in wages, $U$ is the unemployment rate and $A C T$ is the (female) activity rate. We restrict the estimated coefficients to be identical across regions.

To estimate this equation we make use of the panel structure of the data. Panel data are a special type of pooled cross-section/time-series data in which the same individual units are sampled over time. In our analysis both cross-sectional variation and inter-temporal variation can provide useful information. All of the variables exhibit the variation in both dimensions. ${ }^{11}$

Given this type of data and considering the region-specific differences in amenities, climate etc., two different estimation techniques are possible. The first is the so-called within estimation (or fixed-effects estimator) and the other is the random effects estimation. Both take into account the regional fixed effects and focus on the time-series dimension in the data. Fixed effects can come in various forms as they could be regional or climatic differences between regions. Differences in reproduction rates across countries and differences in population structures within countries would make it unlikely that the school age children are distributed randomly across the population. This kind of heterogeneity is also captured in fixed effects. The random effects estimator is preferred over the within (or fixed-effect) estimation if the time-invariant region specific variables are uncorrelated with the regressors. The Hausman test, tests the null hypothesis of a true Random Effects model. In the results

${ }^{11}$ The advantage of panel data comes in a variety of ways: (a) it increases the number of observations; (b) it adds more variability and more information; (c) it permits the data to be treated in two dimensions separately, provided there are enough time periods for which data are available; and (d) it enriches econometric specification such that we can use a fixed effect and a random effects model. 
presented in the next section, the Hausman test rejects in all cases the random effects model given the diversity of regions. Hence the empirical evidence strongly favours fixed effects models. This finding is consistent with most of the empirical literature on European regions; see e.g. Puhani (2001). Parikh and Leuvensteijn (2003) investigate the impact of wage convergence between East and West German regions and find that the relationship between gross migration flows between regions and wage differences is not significant for the latter periods although regional differences in unemployment remain an important determinant of migration between regions.

Table 4.1 reports our results for the basic equations, where we introduce the unemployment rate, the wage proxy and labour participation. Let us first discuss the more familiar GDP and unemployment variables. Both variables have the expected signs and are significant. The interpretation of the estimated coefficients is as follows: a percentage increase in GDP per capita increases the net migration rate by $8.8 / 100$ migrants per 1000 inhabitants, ceteris paribus. For an average region with 2.2 million inhabitants this implies an increase in immigration of around 200 people. A one percent increase in unemployment lowers immigration by 3.2 per 1000 inhabitants. Note that for calculating the effect of a one percentage-point increase in the unemployment rate this figure has to be divided by the appropriate unemployment rate; when evaluated at the average unemployment rate in the sample, the effect of a one percentage-point increase in the unemployment rate is a change in migration of $-3.2 / 9.1=0.35$ per 1000 inhabitants. Hence in an average region with 2.2 million inhabitants and an unemployment rate of $9.1 \%$, an extra number of 770 people leave (or 770 people less come) when the unemployment rate increases with one percentage point (the latter is an increase in unemployment by 22000 people), other things remaining the same. An alternative interpretation of these numbers is that a permanent adverse shock is absorbed for over $90 \%$ by unemployment changes and less than $10 \%$ by net migration. In the US these numbers are $30 \%$ and $65 \%$ respectively, in the short run. In the long run, the shock is entirely absorbed by migration (Blanchard and Katz, 1992). Our methodology differs however from Blanchard and Katz (1992) and Decressin and Fatás (1995). The employment of the Blanchard-Katz methodology confirms our finding. They argue that changes in labour participation absorb shocks. 
Table 4.3: Estimation results

Dependent variable: Net Migration rate $(\mathrm{NM}){ }^{\mathrm{a}}$

\begin{tabular}{|c|c|c|}
\hline Variable & (I) Within & (II) Within \\
\hline \multirow[t]{2}{*}{ GDP } & $8.78^{* * * *}$ & $8.67^{* \ldots * *}$ \\
\hline & {$[3.44]$} & [3.38] \\
\hline \multirow[t]{2}{*}{ UN } & 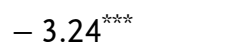 & $-3.27^{\text {*...k }}$ \\
\hline & {$[5.34]$} & {$[5.36]$} \\
\hline \multirow[t]{2}{*}{$\triangle \mathrm{ACTfemale}$} & $-0.16^{* *}$ & $-0.15^{\text {kk }}$ \\
\hline & [2.31] & [1.97] \\
\hline \multirow[t]{2}{*}{$\triangle \mathrm{ACTmale}$} & & -0.04 \\
\hline & & {$[0.45]$} \\
\hline $\mathrm{R}^{2}$ & 0.22 & 0.22 \\
\hline $\mathrm{N}$ & 1161 & 1161 \\
\hline$F(19,1059), F(20,1058)$ & 19.24 & 18.28 \\
\hline $\operatorname{Cov}(u, x B)$ & -0.34 & -0.33 \\
\hline$\sigma_{u}$ & 3.41 & 3.04 \\
\hline$\sigma_{e}$ & 3.06 & 3.07 \\
\hline$P$ & 0.55 & 0.554 \\
\hline $\begin{array}{l}\text { Hausman test based on Wald Chis-quare } \\
\text { test }\end{array}$ & $X^{2}(4)=104.95$ & $\begin{array}{l}X^{2}(5)=105.9 \\
1\end{array}$ \\
\hline
\end{tabular}

*Significantat $10 \%$ level, **Significant at 5\% level and *** Signficant at 1\% level.

Notes:1. Random effect model is rejected by modified Hausman test. The test was modified as the standard Hausman test was not applicable because the differences in asymptotic variance-covariance matrix is not positive definite. 2. Time dummies are included in all equations. 3. $\sigma_{\mathrm{u}}$ is the standard error of the estimated fixed effects or random effects, $\sigma_{\mathrm{e}}$ is the standard error of the estimated residuals and $\rho$ is the fraction of variance attributed to the variation of fixed effects. $4 . \operatorname{Cov}(u, x B)$ reflects the association between explanatory variables and fixed effects.

Now we turn our attention to the participation variable (the alternative adjustment factor introduced by Decressin and Fatás). The estimation shows that female labour participation affects net migration significantly in a negative way. A one percentage-point increase in 
female labour participation decreases net migration by approximately 350 (in a 2.2 million inhabitants region). ${ }^{12}$

When we introduce the difference in both female and male labour participation in the regression we find that only the female activity rate significantly affects migration. Male labour participation enters the equation also negative, but insignificant. This is consistent with the idea that male labour supply is almost inelastic. Summarising, we find that female labour participation affects net migration negatively. This result can be explained by assuming that female labour participation acts as an alternative labour-market adjustment mechanism. In the next section we explore this issue further by estimating a dynamic migration model.

All the above results were obtained for three large countries namely Germany, France and Italy where number of regions exceeds 15 . For France, both unemployment (-ve) and GDP (+ve) had correct signs in the fixed effects model with 20 regions. Female labour participation turned up with negative sign but not significant. For Italy, unemployment and GDP appeared with correct and significant coefficients in the fixed effect model. For Germany (30 regions), unemployment rate has a negative coefficient and significant at $10 \%$ level. There was a change in the base of GDP measure and introduction of dummy from 1995 has a significant coefficient in Germany regressions.

\section{5: A dynamic panel approach: allowing for partial adjustment}

The advantage of the dynamic panel approach is that it allows for lags in the behaviour of agents and as we estimate a reduced form it can be consistent with various hypotheses based on adjustment costs. One of the interpretations is that a fixed proportional adjustment is achieved in one or two periods and that the remainder is spread over time. The smaller the adjustment coefficient, the longer it takes to reach equilibrium or the desired level of net

\footnotetext{
${ }^{12} \mathrm{~A}$ one percent-point increase in the females participation rate causes a fall in the net migration rate of 0.16 migrants per 1000 inhabitants. Multiplied by the average population of 2.2 million results in about 350 .
} 
migration. We propose a model where the dynamics are introduced through lagged dependent and exogenous variables.

Desired migration is $\mathrm{MN}_{\mathrm{it}}{ }^{*}$ and is defined as

$\mathrm{MN}_{\mathrm{it}}{ }^{*}=\mathrm{d}_{1} \log \mathrm{GDP}_{\mathrm{it}}+\mathrm{d}_{2} \mathrm{U}_{\mathrm{it}}+\mathrm{d}_{3} \Delta \ln \mathrm{ACTf}_{\mathrm{it}}+\psi_{\mathrm{i}}+\mathrm{C}_{\mathrm{it}}$

and

$M N_{i t}{ }^{*}-M N_{i t-1}=\pi_{1}\left(M N_{i t}-M N_{i t-1}\right)+\pi_{2}\left(M N_{i t-1}-M N_{i t-2}\right)$

Combining these two and reparameterising yields the following estimating equation.

$$
\begin{gathered}
M N_{i t}=b_{1} \ln G D P_{i t}+b_{3} \ln U_{i t}+b_{5} \Delta \ln A C T f_{i t}+ \\
\lambda_{1} M N_{i t-1}+\lambda_{2} M N_{i t-2}+\alpha_{i}+\eta_{i t}
\end{gathered}
$$

The model we estimate is a first-differenced and dynamic version of the model. Hence, all variables are defined as before but now we use first differences. The fixed effects $\alpha_{i}$ will cancel out in the first differenced equation. We assume that a random sample of $\mathrm{N}$ regions' time series $\left(M N_{i 1} \ldots \ldots \ldots . . M N_{i T}\right)$ is available. $\mathrm{T}$ is small and $\mathrm{N}$ is large. The $\eta_{\mathrm{it}}$ is assumed to have finite moments; in particular $\mathrm{E}\left(\eta_{\mathrm{it}}\right)=\mathrm{E}\left(\eta_{\mathrm{it}} \eta_{\mathrm{is}}\right)=0$ for $\mathrm{t} \neq \mathrm{s}$. We assume lack of serial correlation but not necessarily independence over time. With these assumptions NM lagged two periods or more could be valid instruments in the equations estimated in first differenced form.

We report both one step estimates based on the Arellano-Bond procedure (1991) with robust standard errors to account for autocorrelation and heteroscedasticity and two-step estimates based on the Arellano-Bover (1995) and Blundell and Bond (2000) procedure. The most important results are shown in table 5.1 


\section{Table 5.1: Dependent variable: Net Migration rate $(\mathrm{NM}){ }^{\mathrm{a}}$}

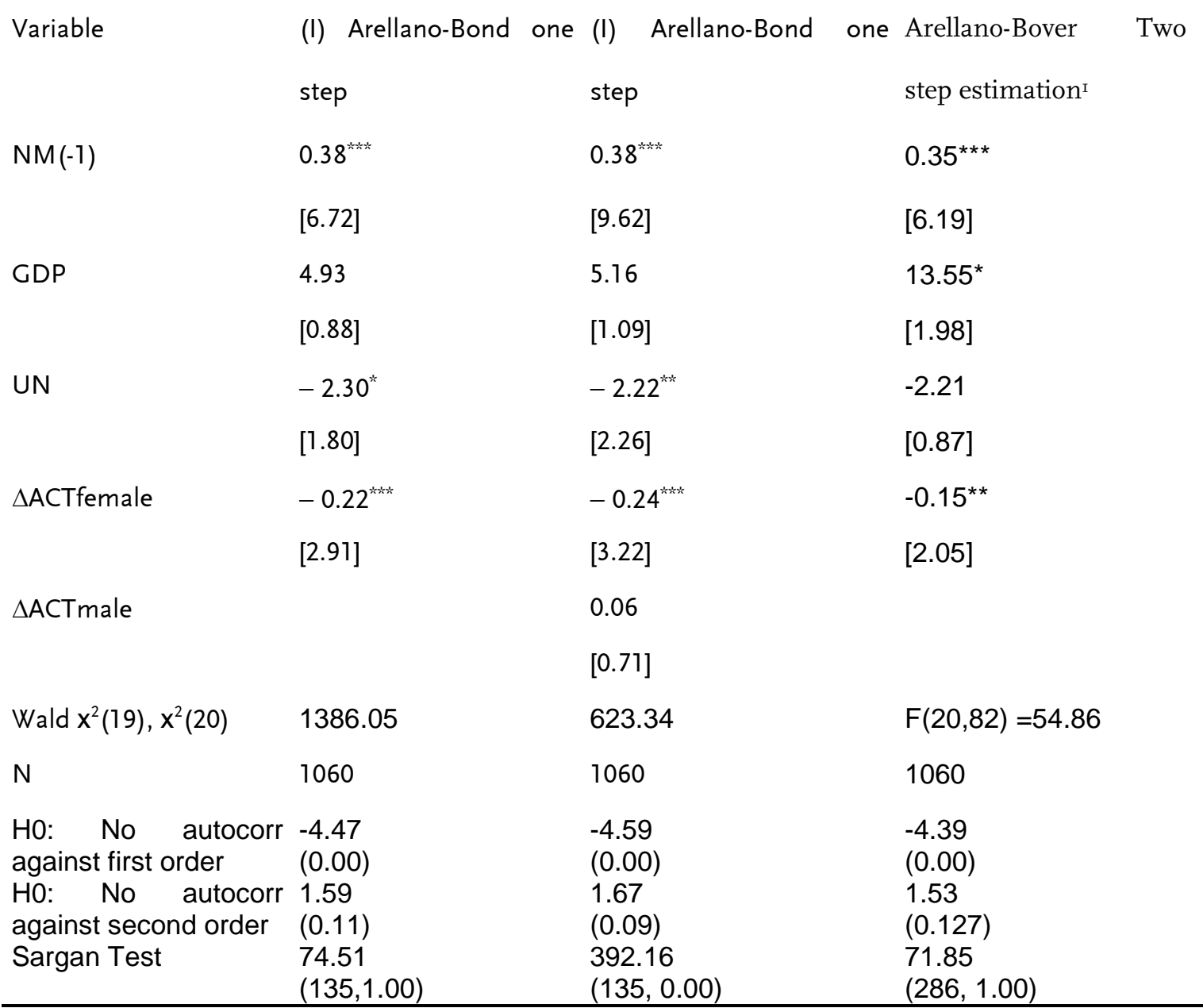

Notes: 1. German dummy and GDP dummy are used. Sample period is 1983-2000, 83 regions. Absolute t-statistics are given in parentheses under the estimates. ***, and *** denote statistical significance at the $10 \%$ level, the 5\% level and the $1 \%$ level respectively. Two step estimation uses the Windmeijer corrected standard errors and gmm type instruments used are lagged migration and dnactfem while exogenous variables are german, year dummies and lgdpnew. Number of instruments is large in relation to number of groups so the generalised inverse is used. No level equation is used and hence the estimation method is difference-GMM as in Bond (1998).

In one step estimation Un, GDP, $\triangle A C T$ female and $\triangle A C T$ male are treated as exogenous variable and they are not instrumented while in two step all of them are instrumented by their lagged values.

The results clearly support the story from the previous sections. The long-run impact of the standard economic variables is as expected: a higher GDP per capita raises the attraction of a region and more unemployment has a negative impact on the net migration rate. Furthermore, the change in the female labour participation rate again enters significantly negative in the 
equation. Hence, the increases in the female labour participation rate indeed lower the net migration rate in the dynamic model. These signs confirm that female labour participation changes can act as a shock absorber against demand shocks.

The second column presents the results when male labour participation is included in the regression as well. The estimated parameter for the male activity rate is small and insignificant. It does not have any serious impact on changes in the female labour participation rates. Other regression parameters also hardly change in relation to the results in the first column. These results also support the negative impact of female labour participation rates on migration rates.

In a dynamic setting the results for France (20 regions) come up with correct signs and female labour participation has a negative and significant coefficient. For Italy, (18 regions) female labour participation does not have anticipated sign suggesting that female labour participation encourages mobility. For Germany (30 regions), female labour participation has a negative coefficient and significant at $10 \%$ level. When Germany is excluded (53 regions together) we find that unemployment coefficient is negative and significant while the female labour participation is negative and not significant in a dynamic model. Female labour participation may not turn up with negative and significant coefficient at a country level as there could be discouraged female workers who take longer to come back into the work force when the economic recovery begins. A long time lag in the adjustment process is sometimes due to the lagged response of the female and male workers who got discouraged during the cyclical downswing and left the work force. Measured unemployment rate does not consider discouraged workers as they are not in the work force. An increase in labour participation at the time of recovery acts as a flexible force to counteract low labour mobility in regions where measured unemployment rate is very low.

Summarising: a dynamic specification of the migration model confirms the hypothesis that changes in (female) labour participation act as an alternative adjustment mechanism.

\section{6: Conclusions}

In this study, we extended the basic Harris-Todaro model to account for the importance of female labour participation as an alternative adjustment mechanism in European regions. Changes in economic activity or in unemployment affect the regional population due to 
migration. This aspect is captured both in the static and the dynamic panel study of 82 European regions. For an average region (with 2.2 million inhabitants, take Noord Brabant in the Netherlands or Hanover in Germany) a one percentage-point increase in unemployment induces 770 persons extra to leave. A one percent increase in per capita income induces an inflow of about 200 persons. It is clear that labour mobility is low.

The important aspect of this study is the sustenance of low labour mobility for a long period of time despite regional disparities. We show that this can partly be explained through the adjustment in female labour participation. Female participation mitigates the adverse effects of low labour mobility. Hence, using a different approach we have a result related to the Decressin and Fatás (1995) finding. 


\section{References}

Arellano M. and S. Bond (1991), "Some Tests of Specification for Panel Data: Monte Carlo Evidence and an Application to Employment Equations" Review of Economic Studies, 58, 277-297

Arellano M. and O. Bover, (1995), Another Look at the Instrumental-Variable Estimation and Error Components Models, Journal of Econometrics, 68, $29-52$.

Barro, R.J. (1996), Getting it Right: Markets and Choices in a Free Society, Cambridge, Massachusetts, MIT Press

Barro, R.J. and X. Sala-i-Martin (1991), “Convergence across states and regions”, Brookings Papers on Economic Activity, no. 1, 107-182.

Bauer, T. and Zimmermann, K. F. (1995), "Integrating the East: The Labour Market Effects of Immigration”, Centre for Economic Policy Research, Discussion Paper No. 1235.

Bayoumi, T. and B. Eichengreen (1993), Shocking Aspects of European Monetary Integration, in: F. Torres and F. Giavazzi (eds.) Adjustment and Growth in the European Monetary Union, Cambridge, p. 193-229.

Blanchard, O. J and L.F. Katz (1992), "Regional Evolutions", Brookings Papers on Economic Activity 0(1), p.1-61.

Blundell, R. W. and S. R. Bond (2000), "GMM Estimation with Persistent Panel Data: An Application to Production Functions", Econometric Reviews, 19, 321-340.

Decressin, J.and A.Fatás (1995), "Regional Labour Market Dynamics in Europe", European Economic Review, 39(9), p.1627-55. 
Devereux, P., J., (2004), Changes in Relative Wages and Family Labour Supply, The Journal of Human Resources, 39, 696-722.

Fatás, A., (1998), "Does EMU Need a Fiscal Federation?", Economic Policy: A European Forum, 0(26), 163-92.

Frankel, J. A. and A.K. Rose (1997), “Is EMU More Justifiable Ex Post Than Ex Ante?”, European Economic Review, 41(3-5), 753-60.

Genre, V., R. Gómez-Salvador and A. Lamo, (2005), “The determinants of labour force participation in the European Union", in: R. Gómez-Salvador, A. Lamo, B. Petrongolo, M. Ward and E. Wasmer (eds.), Labour supply and incentives to work in Europe, Edward Elgar, 197-214.

Gordon, I. (1985), “The Cyclical Interaction Between Regional Migration, Employment and Unemployment: A Time Series Analysis for Scotland”, Scottish Journal of Political Economy, 32, p. 135-159.

Harris, J. R. and M. P. Todaro (1970), "Migration, Unemployment and Development: A Two Sector Analysis", American Economic Review, 60, 126-142.

Hausman, J., and P. Ruud, (1984), "Family Labor Supply with Taxes", American Economic Review, 74, 242-248.

Hicks, J. (1932), The theory of wages, London: Macmillan Publishing Company.

Krugman, P. (1993), Lessons of Massachusetts for EMU, in: F. Torres and F. Giavazzi (eds.) Adjustment and Growth in the European Monetary Union, Cambridge, p. 241-261.

Midelfart-Knarvik, K.H., H.G. Overman, S.J. Redding and A.J. Venables, 2000, The Location of European Industry, European Commission Economic Papers No. 142. 
Parikh, A. and M. Van Leuvensteijn (2003), "Internal Migration in Regions of Germany: A Panel Data Analysis", Applied Economics Quarterly, 49, 173-192.

Pissarides C.A. and I. McMaster (1990), "Regional Migration, Wages and Unemployment: Empirical Evidence and Implications for Policy", Oxford Economic Papers, 42, 812-831.

Puhani, P. A. (2001), "Labour Mobility - An Adjustment Mechanism in Euroland? Empirical Evidence for Western Germany, France and Italy", German Economic Review, 2, 127-140.

Ravenstein, E. (1889),“The laws of migration”, Journal of the Statistical Society, 52, 214301.

Smith A. (1776), Inquiry into the nature and causes of the wealth of nations, London: trahan/Cadell.

Van Leuvensteijn M., and A. Parikh (2002), "How Different are the Determinants of Population Versus Labour Migration in Germany", Applied Economics Letters, 9, 699-703.

Zimmermann, K. (1995), “Tackling the European Migration Problem”, Journal of Economic Perspectives, 9, 45-62. 


\section{Appendix A. Data}

Regions in the panel

We use regional data at the Nuts 2 level from Eurostat (2000). Nuts 2 (nomenclature of territorial units for statistics) subdivides the territory of the European Community into 211 regions. Two regions at the Nuts 2 level are identical to countries: Luxembourg and Denmark. We use data on population changes and economic variables, like GDP, and labour market data, as unemployment and participation rates.

From the available regions we selected the regions which provided the necessary data to construct net migration rates. This provides us with an unbalanced panel of 191 regions with time series up to 18 years (1983-2000).

From the unbalanced panel we constructed a balanced panel with the time-series dimension unaltered and the number of regions reduced to 82 . The following regions are in the balanced panel.

Région Bruxelles-capitale/Brussels hoofdstad gewest, Antwerpen, Limburg, Oost-Vlaanderen , Vlaams Brabant, West-Vlaanderen, Hainaut, Liège , Luxembourg, Namur, Denmark , Stuttgart, Karlsruhe , Freiburg, Tübingen , Oberbayern, Niederbayern, Oberpfalz, Oberfranken, Mittelfranken, Unterfranken, Schwaben , Berlin, Brandenburg, Bremen , Hamburg, Darmstadt, Gießen, Kassel , Braunschweig, Hannover , Lüneburg, Weser-Ems , Düsseldorf , Köln , Münster, Detmold , Arnsberg, Koblenz , Trier , Rheinhessen-Pfalz , Saarland , SchleswigHolstein , Thessalia , Kriti, Île de France , Champagne-Ardenne , Picardie , Haute-Normandie , Centre , BasseNormandie , Bourgogne, Nord - Pas-de-Calais, Lorraine, Alsace, Franche-Comté , Pays de la Loire , Bretagne , Poitou-Charentes , Aquitaine , Midi-Pyrénées , Limousin , Rhône-Alpes , Auvergne , Languedoc-Roussillon , Provence-Alpes-Côte d'Azur, Corse, Piemonte, Valle d'Aosta , Lombardia , Trentino-Alto Adige, Veneto , FriuliVenezia Giulia , Emilia-Romagna , Toscana , Umbria , Marche , Lazio , Abruzzo , Molise , Campania , Puglia , Basilicata , Calabria , Sicilia, Sardegna , Luxembourg

Definitions of the variables:

GDP Log of gross domestic product per inhabitant at Purchasing Power Parities at NUTS level 2.

The following data are the results of a survey. The survey refers exclusively to private households. The labour force (or active population or working population) was defined as comprising persons in employment and the unemployed. All those persons who are not classified as employed or unemployed are defined as inactive. Activity rates represent the labour force as a percentage of the population of working age (15 years or more for the post-1991 series, 14 years or more for the series between 1983 and 1991).

\section{ACTfemale/male Activity rates of females/males}

Unemployed persons are those who, during the reference period of the interview, were aged 15 years or over, without work, available for work within the next two weeks and had used an active method of seeking work at some time during the previous four weeks.

U Log of unemployment rates at NUTS level 2

The following data are not used directly in the estimation but to construct net migration rates.

Pop Population at 1st January

Births Live births

Deaths Deaths

The data on migration rates are derived from population changes that are not explained by births and deaths. The figures thus constructed report the difference between immigration and emigration. The immigrant either resided in a different region within the same country, a region in some other EU country or some non-EU country. The net change in population due to migration to offset region-specific shocks is relevant. The source of the migrants is (economically) not relevant. The information on gross flows between regions would facilitate the analysis of different push and pull factors within an economy. Such information is, however, not available between regions of the EU economies. 